\begin{tabular}{|c|c|c|c|}
\hline & \multicolumn{2}{|c|}{ RESEARCH ARTICLE ARAŞTIRMA MAKALESI } & \\
\hline Title of Article & \multicolumn{2}{|c|}{$\begin{array}{c}\text { Architectural and Gastronomic Factor } \\
\text { Integrity Analysis in Urban Branding: } \\
\text { Historical Cheesemongers Bazaar and Van } \\
\text { Herby Cheese }\end{array}$} & \\
\hline $\begin{array}{l}\text { Corresponding } \\
\text { Author }\end{array}$ & \multicolumn{2}{|c|}{$\begin{array}{l}\text { Gülçinay BAŞDOĞAN DENİZ } \\
\text { İskenderun Teknik Üniversitesi Şehir ve Bölge Planlama Bölümü, } \\
\text { gulcinay.basdogan@iste.edu.tr }\end{array}$} & \\
\hline $\begin{array}{l}\text { Received Date } \\
\text { Accepted Date }\end{array}$ & \multicolumn{2}{|l|}{$\begin{array}{l}04.05 .2020 \\
01.10 .2020\end{array}$} & \\
\hline Author / Authors & $\begin{array}{l}\text { Gülçinay BAŞDOĞAN DENIZ } \\
\text { Berivan TURAN }\end{array}$ & $\begin{array}{l}\text { ORCID: 0000-0003-3281-911X } \\
\text { ORCID: 0000-0001-9623-1599 }\end{array}$ & \\
\hline How to Cite & \multicolumn{2}{|c|}{$\begin{array}{l}\text { BAŞDOĞAN DENIZ, G., (2020). Kent Markalaşmasında Mimari ve Gastronomik } \\
\text { Unsur Bütünlüğ̈̈ Analizi: Tarihi Peynirciler Çarşısı ve Van Otlu Peyniri, Kent } \\
\text { Akademisi, Volume, 13, Issue 3, Pages 443-459 }\end{array}$} & $\begin{array}{l}\text { Kent Akademisi } \\
\text { Urban Academy }\end{array}$ \\
\hline
\end{tabular}

\title{
Kent Markalaşmasında Mimari ve Gastronomik Unsur Bütünlüğü Analizi: Tarihi Peynirciler Çarşısı ve Van Otlu Peyniri
}

\begin{abstract}
:
Although Historical Cheesemongers Bazaar was built in the first years of the republican period, it was built with the logic of the bazaar in the Ottoman classical period.Research in line with these architectural features; It focused on determining the effect of the restoration project of the Historical Cheesemonger Research in line with these architectural features; It focused on determining the effect of the restoration project of the Historic Cheese Market, which was built in 2018 with the support of the Eastern Anatolia Project Regional Development Administration, on the historical structure, branding of places and cities, sale of herby cheese, shopkeepers and local people. The bazaar used by the offal sellers and cheese mongers before the restoration was rented only to tradesmen selling cheese after the restoration.Thus, space quality of the Bazaar has been improved in terms of health and aesthetics.However, some problems have been determined in the implementation of the restoration project regarding workmanship and the materials used. As a result of the study; Restoration Project of Historical Cheesemongers Bazaar; although it has contributed positively to cultural heritage values, place branding and urban identity in terms of historical structure and gastronomy, it was observed that it did not to achieve the expected increase in herby cheese sales in terms of economy.
\end{abstract}

KEYWORDS: Place and City Branding, Herby Cheese, Restoration, Historical Cheesemongers Bazaar

\footnotetext{
${ }^{1}$ İskenderun Technical University, Faculty of Architecture, Department of City and Regional Planning, gulcinay.basdogan@iste.edu.tr

${ }^{2}$ Van Yuzuncu Y11 University, Faculty Of Architecture and Design, Department of Landscape Architecture M.Sc. Student, turan5327@gmail.com
} 
ÖZ:

Tarihi Peynirciler Çarşısı Cumhuriyet döneminin ilk yıllarında yapılmıș olmasına rağmen, Osmanlı klasik dönem arasta şeklinde inşa edilmiştir. Bu mimari özellikler doğrultusunda araştırma; Tarihi Peynirciler Çarşısı'nın 2018 yılında Doğu Anadolu Projesi Bölge Kalkınma İdaresi Başkanlı̆̆ desteği ile yapılan restorasyon projesinin tarihi yapıya, yer ve kent markalaşmasına, otlu peynir satışlarına, esnaf ve yerli halk memnuniyetine etkisinin belirlenmesine odaklanmıştır. Buna göre restorasyonun kente, yapıya ve esnafa yönelik olumlu ve olumsuz etkilerini belirlemek için çarşı esnafiyla yüz yüze mülakatlar yapılmıştır. Restorasyon öncesi sakatatçılar ve peynircilerin kullandığı çarşı restorasyon sonrası sadece peynir satışı yapan esnafa kiralanmıştır. Böylelikle Çarşının sağlık ve estetik açısından mekan kalitesi iyileştirilmiştir. Ancak restorasyon projesinin uygulanmasında işçilik ve kullanılan malzeme konusunda bazı sorunlar tespit edilmiştir. Yapılan çalışma sonucunda; Tarihi Peynirciler Çarşısı Restorasyon projesinin; tarihi yapı ve gastronomi açısından kültürel miras değerlerine, yer markalaşmasına ve kent kimliğine olumlu katkı sağlamasına rağmen ekonomik yönden otlu peynir satışlarında beklenen artışı sağlayamadığı görülmüş̧ür.

ANAHTAR KELIMELER: Yer ve Kent Markalama, Otlu Peynir, Restorasyon, Tarihi Peynirciler Çarşısı

\section{GíRiş:}

Küreselleşme, serbest piyasa ekonomisinin Dünya da hakim olmasıyla birlikte sınırsız coğrafyalar oluşturarak ülkeler arasında rekabete neden olmaktadır. Bu süreçte, ürün ve hizmetler arasındaki farklılıklar pazarlamada markalamayı/markalaşmayı gerekli kılmaktadır.

Ürün ve hizmetler kapsamında değerlendirilen markalama, küresel rekabet ortamında kentlerin sermayeyi çekmesi için bir araç olarak kullanılmaktadır. Kentler farklılıklarını (doğal ve kültür değerler, turizm, hizmet kalitesi, yöresel ürünler, kimlik, vb.) pazarlayabilmek için markalamaya yönelik kentsel stratejiler oluşturmaktadır. Buna göre araştırma; markalama kavramını akademik literatürde kent markalama/markalaştırma yaklaşımlarıyla inceleyerek Van kentinin önemli bir marka değeri olan Van Otlu Peynirin satışının yapıldığı Tarihi Peynirciler Çarşısının restorasyon projesini yer markalama stratejisi kapsamında değerlendirmeyi hedeflemektedir.

\section{Markalama ve Kent Markalaması}

Markalama ve pazarlama kavramları birbirinden farklı anlamlar içermektedir. Markalaşma pazarlamanın bir parçasıdır ve hedef grupların zihninde algı, imaj, zihinsel ilişkiler, farkındalık ve itibar ile ilişkili bir pazarlama aracıdır. Marka bilinci oluşturma, marka yönetim sürecini kapsamaktadır. "Pazarda önemli ve farklılaşmış bir varlık oluşturmak" için tasarlanan faaliyetlerle marka öne çıkmaktadır. Bu nedenle, markanın oluşması için, var olması veya yaratılma sürecinde olması gerekir. Bir yer söz konusu olduğunda ise, markalaşma tüm ticari faaliyetleri kapsayacak bir kimlik yaratmaktadır (Vuignier, 2016:5-6).

Kent Markalama/markalaştırma kavramsal olarak akademik literatürde; yer pazarlaması (place marketing), yer markaları (place brands) ve yer markalama (place branding) kavramları ile ilişkilendirilmiştir. Yer pazarlaması; pazarlama araçlarının şehirler, kasabalar, bölgeler ve topluluklar gibi coğrafi konumlara uygulanmasını ifade etmektedir. Buna göre yer pazarlaması; şehrin müşterileri ve genel olarak yerli halk için önemli kentsel önerilerin oluşturulması, sunulması ve iletilmesi için ortaklaşa, müşteri odaklı bir felsefe tarafindan desteklenen pazarlama araçlarının koordineli kullanımı olarak tanımlanmaktadır. Yer markaları ise; yerlere anlam veya değer katmayı amaçlayan sembolik yapılardan oluşmaktadır. Markalar, yerleri tanımlayan ve yerleri kültürel anlamla iç içe geçiren ilişkileri çağrıştıran işaretler olarak değerlendirilmektedir. Son olarak yer markalama ise; genellikle pozitif ilişkileri harekete geçirmek ve yeri diğerlerinden ayırmak amacıyla bölgeler, şehirler veya topluluklar gibi coğrafi konumlar için markaların geliştirilmesini ifade etmektedir. Yer markalaması, yer pazarlamasında, bir yerle belirli duygusal ve psikolojik ilişkiler kurarak insanların fikirlerini etkilemeyi içeren unsurlar taşımaktadır (Eshuis vd, 2014:153-155). Buna göre yer markalama pazarlama, imaj, kimlik, coğrafi isim, iletişim ve yer teşviki ile ilişkilidir. 
Son zamanlarda yer pazarlaması ve marka bilinci oluşturmaya yönelik uygulamalarda çeşitli değişiklikler meydana gelmiştir. Yer pazarlaması uygulaması, belirli hedef grupların ihtiyaçlarını karşılamaya çalışmaktan, bölgesel kalkınmaya odaklanan daha gelişmiş ve farklılaştırılmış stratejilere evrilmiştir. Bu değişim/dönüşüme göre artık sadece bir yeri "satmak" yeterli olmamaktadır. Bunun yerine, mevcut ve potansiyel hedef gruplar ile mevcut tesisler, yerli halk ve kuruluşlar arasındaki etkileşimi içeren bir pazarlama mantığının kullanılması, uzun vadeli bir vizyon ve beklentilere yönelik stratejilerin oluşturulması gerekmektedir (Vuignier, 2016:13).

Cerreta ve Daldanise (2017: 732) yer pazarlamasını bir mekanın kendi kimliğini yansıtması için pazara yönelik bir stratejinin geliştirilmesini amaçlayan bir süreç olarak tanımlanmaktadır. Bu tanıma göre yer pazarlaması, yerel talebin yönetimi için bir üretim kültürü olarak yorumlanmaktadır.

Kentsel araştırmalarda yer pazarlamasından daha çok yer pazarlamanın bir unsuru olan yer tanıtımına odaklanılmıştır. Buna göre araştırmalar; yer pazarlama stratejisi, yasal, politik ve ekonomik çerçevede somut önlemleri içeren tanıtım kampanyaları, turizm, kültürel ve spor ürünleri, etkinlik ve anıtlara yönelik flagship projelerden oluşmaktadır. Araştırmalarda yer markalama ise; kültür, tarih, yere bağlılık ve yaşam kalitesi ile ilişkilendirilmiştir. Bu bağlamda hedef grupların yaşam kalitesi ve kamu sektöründeki hizmet kalitesi markalaşmanın bir parçasını temsil etmektedir (Parker vd, 2015:1092-1995).

Kentler; küresel rekabet ortamında/yarışında yer alabilmek ve yatırımları çekebilmek için farklılıklarını ürüne dönüştürerek markalaşma ve pazarlamayı amaçlayan kentsel stratejiler oluşturmaktadır. Kent markalaşması; kentteki tüm bilgilerin belli bir amaca yönelik olarak sembolleştirilmesi olarak tanımlanmaktadır (Akturan ve Oğuztimur, 2016:118). Kavaratsiz (2004:58), kent markalaşmasının kent imajıyla doğrudan ilişkili ve kent pazarlamasının bir parçası olduğunu ifade etmiş̧ir. $\mathrm{Bu}$ tanıma göre literatürde üç farklı yer markalama yaklaşımı bulunmaktadır. Bunlardan birincisi coğrafi isimlendirme ile markalaşma, ikincisi ürün ve yeri birlikte kullanarak markalaşma üçüncüsü ise yer yönetimi olarak markalaşmadır (Kavaratsiz ve Ashworth, 2006:190). Mommaas (2004:516) markalaşmanın, kente sadece ekonomik etkisinin olmadığını aynı zamanda toplumsal bütünleşme gibi sosyo-kültürel etkisinin de olduğunu belirtmiştir. Kentlerdeki markalaşma ağırlıklı olarak geleneksel ürün/üretim ve mimari yapılarda görülmektedir.

Başarılı bir kent markalaşmasının bir takım unsurları vardır. Bu unsurlar; kültür, kültürel miras, iklim, insan, turizm, kongre, konferans ve festivaller, dış İlişkiler ve yerel yönetim, eğitim, sanat ve spor, gastronomi, ulaşım ve dindir. Bu unsurlar birbirinden ayrı olarak kentin marka değeri açısından önemlidir (Zengin, 2017:53).

Kent markalaşmasında yerel yönetimlerin oluşturmuş olduğu kentsel politikalar/stratejiler önem arz etmektedir. Yerel yönetimler, kentin ekonomik, sosyal ve kültürel kalkınması için farklı planlama fonksiyonlarını düzenleyerek kaynakların sürdürülebilirliği için kentin kültürel ürünlerini ve marka oluşturabilecek kaynaklarını etkin kullanabilmektedirler.

Seisdedos ve Vaggione (2005:1) bir kent markasının oluşturulmasında, bir kentsel bölgenin niteliklerinin hem yönetsel hem de pazarlama teknikleri açısından sosyo-ekonomik ve mekânsal planlama kapsamında kentsel gelişim stratejilerine göre düşünülmesi gerektiğini belirtmişlerdir.

Kent markalaşma süreci stratejik bir yaklaşım gerektirmektedir. Bu nedenle yerel yönetimlerle birlikte yerel halkında bu sürece katılması önemlidir. Marka kent oluşturma süreci ilk olarak stratejik marka kent analizi ile başlamaktadır. Kentin markalaşmasına yönelik SWOT analizi yapılarak kentin imajı, kimliği, zayıf ve güçlü yönleri ile misyon ve vizyon belirlenerek markalaşma stratejileri oluşturulmaktadır. Stratejik analizlerde belirlenen hedefler doğrultusunda; kent kimliği, kimliğin imaja dönüşümü, kent marka kişiliği, konumlandırma, kent hikayesi oluşturma, logo ve sembol, slogan ve marka ilişimi kapsamında çalışmalar yapılmaktadır (Zengin, 2017:61-96). 
Bu bağlamda araştırma; Cumhuriyet döneminde yapılan Tarihi Peynirciler Çarşısı Restorasyon Projesi’nin kentin markalaşmasına, mimari ve gastronomi anlamında kültürel mirasın korunması ve yaşatılmasına, otlu peynir satı̧slarına, esnaf ve yerli halk memnuniyetine etkisini belirlemesi açısından önem arz etmektedir. Yerel aktörlerden Van Büyükşehir Belediyesi, bölgesel aktörlerden ise DAP Bölge Kalkınma İdaresi Başkanlı̆̆ı'nın ortak yürüttüğü restorasyon projesi aynı zamanda yerel ve bölgesel aktörlerin markalaşmaya yönelik ortak bir çalışması olması açısından da anlamlıdır.

\subsection{Markalaşmaya Yönelik Bölgesel ve Yerel Aktörlerin Stratejileri}

Bu bölümde otlu peynir ve Tarihi Peynirciler Çarşısı'nın markalaşma ve yer markalamasına yönelik olarak kentsel ve bölgesel stratejileri; kültürel miras, gastronomi ve coğrafi işaret kapsamında değerlendirilmiştir. Buna göre bölgesel aktörlerden DAP Bölge Kalkınma İdaresi Başkanlı̆̆ tarafından hazırlanan ve 2014-2018 yıllarını kapsayan Doğu Anadolu Projesi (DAP) Eylem Planında gıda ürünleri ve kırsal kalkınma hedefinde "işlenmişs tarımsal ürünlere ilişskin olarak DAP markalaşma ve pazarlama stratejisi hazırlanması" amacıyla tarım ürünleri üzerinden bir markalaşmaya gidilmesi hedeflenmiştir. DAKA tarafından hazırlanan TRB2 Bölgesi 2014-2023 Bölge Planı'nın da ise "Ekonomik Dönüşüm ve Büyüme" olan birinci gelişme ekseninde markalaşma stratejisinin benimsenmesi ve coğrafi işaretlerin belirlenerek yöresel ürünlerin tescillerinin sağlanması hedeflenmiştir. İkinci gelişme ekseninde ise "Yaşanılabilir Mekânlar" kapsamında kent kimliği ve kent dokusuna yönelik kentsel tasarım çalışmalarının yürütülmesi, kentsel yaşam kalitesinin iyileştirilmesi ve kentin tarihi mimari dokusunun korunması amaçlanmıştır. Yerel aktörlerden Van Büyükşehir Belediyesi ise 2015-2019 Strateji Planında kültürel miras alanlarının turizme kazandırılması, yaşam kalitesinin iyileştirilmesi ve Kahvaltıcılar Caddesi önerisi ile kültürel miras ve yerel gastronomiye vurgu yaparak proje önerileri geliştirmiştir (DAKA, 2013; DAP, 2014; Van Büyükşehir Belediyesi, 2014). Buna göre DAP Bölge Kalkınma İdaresi Başkanlığı markalaşma ve pazarlamaya yönelik oluşturmuş olduğu bölgesel planlama stratejisi ile otlu peynir satışının yapıldığı Tarihi Peynirciler Çarşısı Restorasyon Projesine destek olmuştur.

\subsection{Gastronomi Değeri Olarak Van Kahvaltısı ve Van Otlu Peyniri}

Bir kentin markalaşmasında kültürel miras, gastronomi, yerellik, ulusal ve uluslararası etkinlikler, uluslararası platformda tanınırlık, marka tescili ve coğrafi işaretler önem arz etmektedir. Buna göre Van kenti kültürel miras değerleri dışında gastronomi konusunda da zengin bir kültüre sahiptir (Cihangir vd, 2019:748). Gastronomi değeri yüksek yerel ürünlerin en önemlisi ise Van Kahvaltısıdır. Van Kahvaltısı, ulusa1 etkinlik kapsamında Haziran 2014 tarihinde 51 bin 793 kişiyle en kalabalık kahvaltı sofrası olarak Guinness Rekorlar Kitabı'na girmiştir (URL 1). Bu etkinlik Van kentinin ve Van Kahvaltısının uluslararası düzeyde tanınırlığını attırmıştır. Van Ticaret ve Sanayi Odası, kent ile özdeşleşen kahvaltının tescillenmesi ve standardının belirlenmesi amacıyla 13 Şubat 2014 tarihinde Türk Patent Enstitüsü'ne müracaat ederek 17 Şubat 2015 tarihinde "Van Kahvaltısı Marka Tescil Belgesi" almıştır (URL 2). Ayrıca Van Kahvaltısının uluslararası platformda tanınırlığının artıılması için Van Yüzüncü Yıl Üniversitesi (YYÜ) ile Kültür ve Turizm İl Müdürlüğü, Van Kahvaltısının UNESCO İnsanlığın Somut Olmayan Kültürel Mirası Listesi'ne dahil edilmesi için başvuruda bulunmuştur (URL 3). Kentin markalaşmasında önemli bir değer oluşturan Van Kahvaltısının en önemli besini ise yöreye özgü endemik bitki türleri ile yapılan otlu peynirdir.

Van Otlu Peyniri, yöreye özgü olarak Van'ın ilçe ve köylerindeki dağlardan toplanan sirmo/sirik, mendi, heliz, kekik, yabani nane, siyabo vb. gibi yaklaşık 20 adet endemik bitkinin farklı miktarlarda eklenmesiyle hazırlanmaktadır (Şekil 1) (Turan, 2019). Hazırlanan otlu peynirler Van Tarihi Peynirciler Çarşısında satılmakta ve ekonomik değer yaratmaktadır. Van Otlu Peyniri, Van Ticaret ve Sanayi Odasının, Türk Patent Kurumu'ndan 31 Aralık 2018 tarihinde 405 No-Menşe adı ile "Coğrafi İ̧saret” tescili alarak markalaşmıştır (Demirhan vd, 2019:665). 


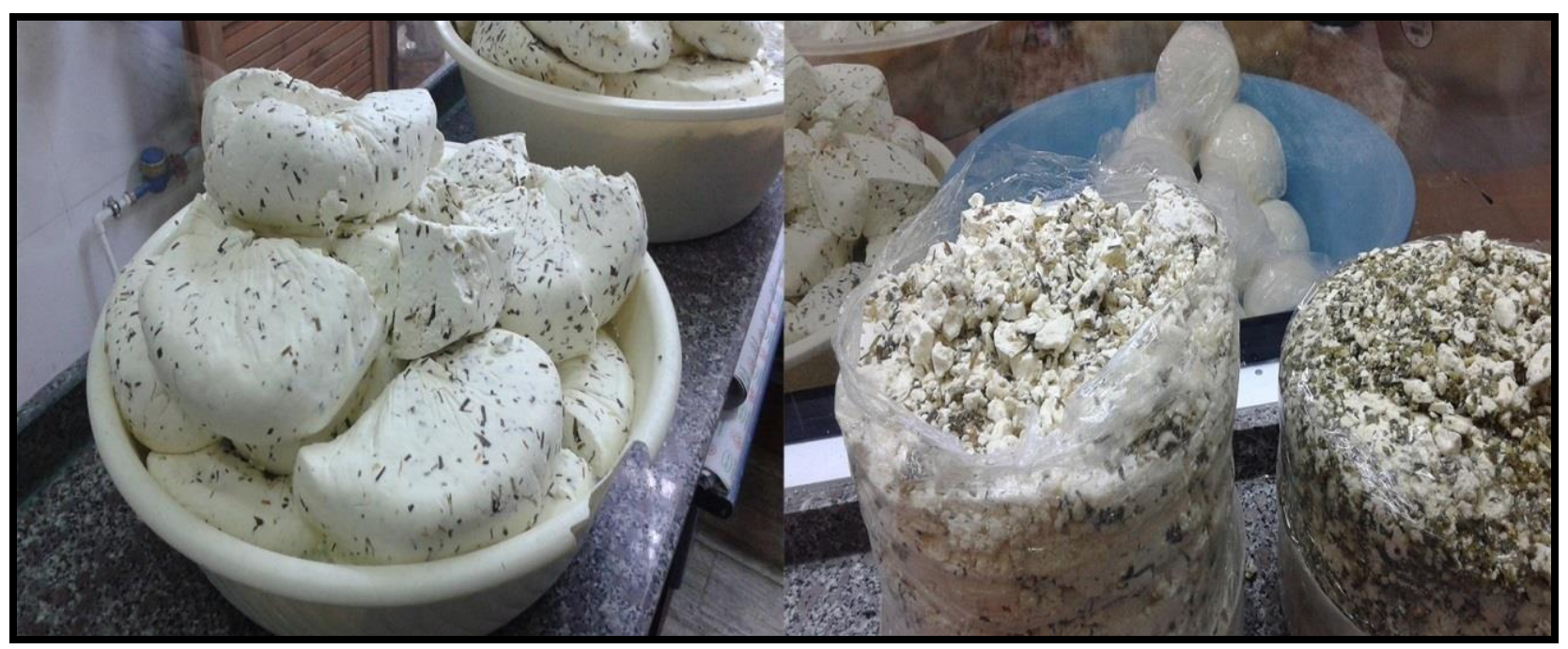

Şekil 1. Van Otlu Peyniri (Berivan Turan, 2019)

\section{Kültürel Miras Değeri Olarak Tarihi Peynirciler Çarşısı Ve Mimari Özelliği}

\subsection{Tarihi Peynirciler Çarşısı Konumu}

Tarihi Peynirciler Çarşısı, Van İli İpekyolu İlçesi Çarşı Mahallesi 28 Pafta 196 Ada 1 ve 2 nolu parseller üzerinde ve kent merkezinin en işlek caddesi olan Cumhuriyet Caddesine paralel batı yönünde yaklaşık 50 metre mesafe uzaklıkta bulunmaktadır (Şekil 2). Bitişik yapı nizamında inşa edilen Peynirciler Çarşısı'nın yapım tarihi tam olarak bilinmemekle birlikte kullanılan malzeme ve yapım tekniği incelendiğinde, 1900 yılların başında inşa edildiği tahmin edilmektedir (Van Büyükşehir Belediyesi, 2017:1-7). Yapının Cumhuriyet döneminde, Yeni Van'ın kuruluş yıllarında, Belediye Başkanı Şaban Boysan tarafından "Kapalı Sebze Hali” olarak tahmini 1933 yılında yapıldığı düşünülmektedir (Şekil 3). Peynirciler Çarşısı, Van kentinin alışveriş yapılan ilk kapalı çarşısıdır. 1990'lı yıllarda Çarşı'da yaş sebze meyve, şarküteri ürünleri satan işyerleri ve kasaplar yer almıştır. Köklü esnafların ayrılmaları sonucu tarihi bina Peynirciler Çarşısı'na dönüşmüştür (URL 4). 


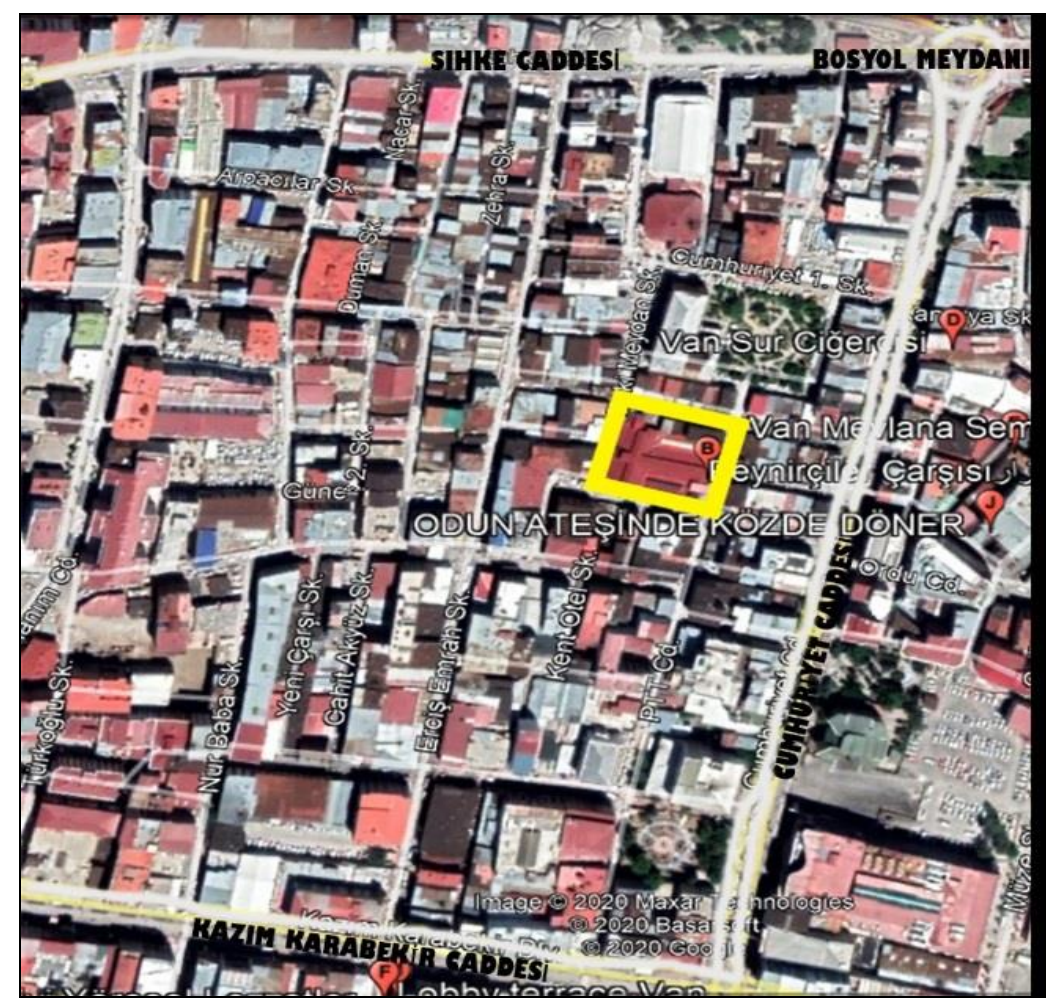

Şekil 2. Tarihi Peynirciler Çarş1sı Uydu Görüntüsü (Google Earth, 2019)

1900'lü yıllarda kentin ilk kapalı alışveriş merkezi niteliğinde olan çarşı yıllar geçmesine rağmen daima aktif olarak alış-veriş yapılan bir yer olma özelliğini korumuştur. Konum itibariyle bugün de kentin en işlek caddeleri ve ana aksları olan Cumhuriyet Caddesi, Kazım Karabekir Caddesi ve Sihke Caddesi'nin ortasında yer almaktadır. Ayrıca, kentin odak noktası olan Beşyol Meydanı'na da yakın mesafede bulunmaktır. Kent halkının ve dışardan gelen misafirlerin rahatlıkla ulaşabileceği bir konuma sahip olan çarşı marka değeri taşıyan otlu peynirin satışıyla ve mimari yapısıyla kentin önemli bir değeri niteliğindedir.

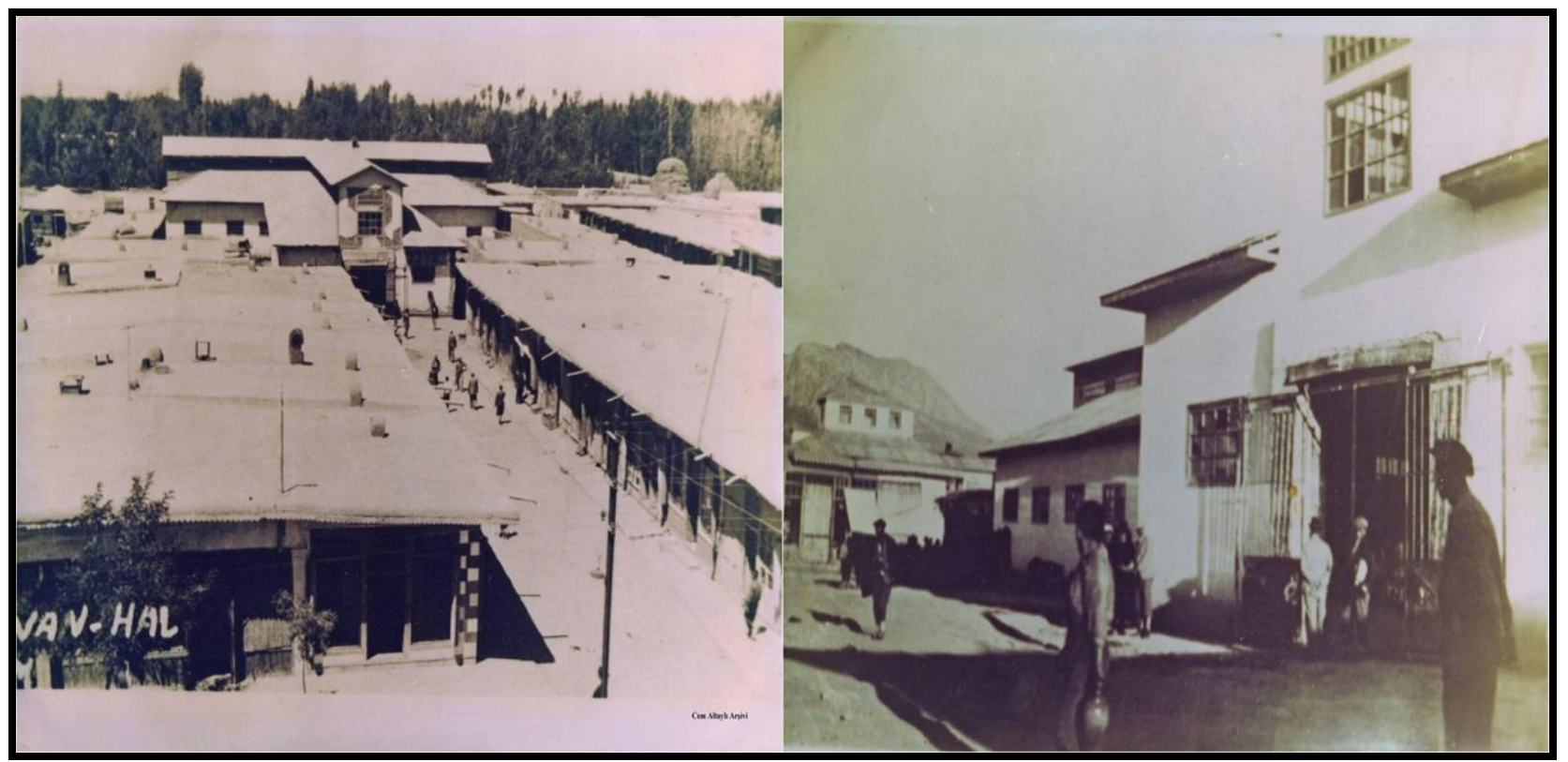

Şekil 3. Tarihi Peynirciler Çarşısı Eski Görünümü (Van Büyükşehir Belediyesi Arşivi, 2019)

Architectural and Gastronomic Factor Integrity Analysis in Urban Branding: Historical Cheesemongers Bazaar and Van Herby Cheese

Journal of Urban Academy | Volume: 13 Issue: 3 | ISSN: 2146-9229

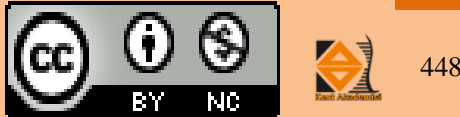




\subsection{Mimari Özellik}

Tarihi Peynirciler Çarşısı mimari açıdan arasta özelliği sergilemektedir. Osmanlı döneminde, kentin çarşıs1/ ticari merkezi, genellikle tek bir bölge olup, bedesten, han ve arastalardan oluşmuştur. Arastalar genellikle aynı esnaf grubuna ait dükkanların bir sokak üzerinde karşılıklı sıralanması ile meydana gelmiş̧ir. Arastalar, çarşı içinde sokaklar şeklinde olabildiği gibi bağımsız veya bir külliyenin parçası olarak da inşa edilmiştir (Akar, 2009: 267-272). Arastaların en güzel örneği Mimar Sinan'ın ustalık eserim dediği Selimiye Cami Külliyesi'nde bulunan Edirne Selimiye Arastasıdır. Tarihi Peynirciler Çarşısı ise Cumhuriyet döneminde yapılmasına karşın Osmanlı Klasik Dönem mimarisindeki arasta çarşı mantığıyla yapılmıştır (Top, 2019) ${ }^{3}$. Osmanlı'daki arasta çarşı modeline incelendiğinde yapım, plan, teknik, malzeme ve amacına göre Tarihi Peynirciler Çarşısı'nın da bu modelle yapıldığı ve Edirne Selimiye Arastasına benzediği düşünülmektedir (Şekil 4-5-6). Tablo 1'de Tarihi Peynirciler Çarşısı ile Edirne Selimiye Arastasının mimari özellikleri verilmiştir. Buna göre her iki yapıda T plan şeklinde ve tek katlı, fener çatılı ve aynı esnaf grubuna hizmet etmektedir.

Tablo 1.Tarihi Peynirciler Çarşısı ile Edirne Selimiye Arastasının Mimari Özellikleri

\begin{tabular}{|c|c|}
\hline $\begin{array}{c}\text { Tarihi Peynirciler Çarşısı Mimari ve Teknik } \\
\text { Özellikleri }\end{array}$ & $\begin{array}{c}\text { Edirne Selimiye Arastası Mimari ve Teknik } \\
\text { Özellikleri }\end{array}$ \\
\hline $\begin{array}{l}\begin{array}{l}\text { Cumhuriyet döneminin } \\
\text { yapılmıştır. }\end{array} \\
\text { ylk }\end{array}$ & $\begin{array}{l}\text { Osmanlı klasik döneminde Sultan III. Murat zamanında } \\
1590 \text { yılında yapılmıştır. }\end{array}$ \\
\hline T plan şeklinde tek katlı tasarlanmıştır. & T plan şeklinde tek katlı tasarlanmıştır \\
\hline $\begin{array}{l}\text { Yapıldığı dönemin geleneksel malzemesi olan } \\
\text { kerpiç ve ahşap kullanılmıştır. }\end{array}$ & $\begin{array}{l}\text { Yapıldı̆̆ dönemin geleneksel malzemesi olan taş ve } \\
\text { ahşap kullanılmıştır. }\end{array}$ \\
\hline $\begin{array}{l}\text { Aynı esnaf grubuna ait dükkanların bir sokak } \\
\text { üzerinde karş1lklı sıralanması ile meydana gelmiştir. }\end{array}$ & $\begin{array}{l}\text { Aynı esnaf grubuna ait dükkanların bir sokak üzerinde } \\
\text { karşılıklı sıralanması ile meydana gelmiştir. }\end{array}$ \\
\hline $\begin{array}{l}\begin{array}{l}\text { Ana giriş olan } \\
\text { kullanılmıştır. }\end{array} \\
\text { orta }\end{array}$ & Ana giriş olan orta kısımda fenerli çatı kullanılmıştır. \\
\hline $\begin{array}{l}\text { Başlangıçta dört tane giriş-çıkış olacak şekilde } \\
\text { tasarlanmıştır. Bitişik nizamdan dolayı bir giriş } \\
\text { kapanmış ve sonradan eklenen kısımlardan dolayı şu } \\
\text { an yedi tane giriş-çııış bulunmaktadır. }\end{array}$ & $\begin{array}{l}\text { Başlangıçta dört tane giriş-çıkış olacak şekilde } \\
\text { tasarlanmıştır ve şu an dört giriş-çıkış bulunmaktadır. }\end{array}$ \\
\hline $\begin{array}{l}\mathrm{T} \text { planda kolların birleştiği noktada şadırvan } \\
\text { bulunmaktaydı. Restorasyon sonrası kaldırılmıştır. }\end{array}$ & $\begin{array}{l}\text { T planda ortada kubbe bulunmaktadır. Ve esnaf her sabah } \\
\text { işe başlamadan önce toplanıp burada dua ettiği için buna } \\
\text { dua kubbesi denmektedir. }\end{array}$ \\
\hline Bağımsız bir kapalı çarşı olarak tasarlanmıştır. & $\begin{array}{l}\text { Selimiye Cami Külliyesi içerisinde kapalı çarşı olarak } \\
\text { tasarlanmıştır. }\end{array}$ \\
\hline $\begin{array}{l}\text { Tahmini yapım yılına bakıldı̆̆ } ı \text { zaman Van ilinin } \\
\text { merkezi olarak belirlenen yerleşimin yapıldığı yerde } \\
\text { ticaret yapılması amacıyla inşa edilmiştir. }\end{array}$ & $\begin{array}{l}\text { Arastalar genelde yerleşimin yapıldığ merkez sayılan } \\
\text { güzergahlarda gelir getirmek amacıyla inşa edilmektedir. }\end{array}$ \\
\hline $\begin{array}{l}\text { Van'a gelen yerli ve yabancı turistlerin tercih } \\
\text { ettikleri bir alışveriş noktasıdır. }\end{array}$ & $\begin{array}{l}\text { Edirne Selimiye Camisi'ni ziyarete gelen yerli ve yabancı } \\
\text { turistlerin tercih ettikleri bir alışveriş noktasıdır. }\end{array}$ \\
\hline
\end{tabular}

\footnotetext{
${ }^{3}$ Top, M. 2019. 31.12. 2019 tarihinde Van Yüzüncü Y1l Üniversitesi Edebiyat Fakültesi Sanat Tarihi Bölümü Öğretim Üyesi Doç.Dr. Mehmet Top ile yüz yüze derinlemesine mülakat gerçekleştirilmiştir.
} 


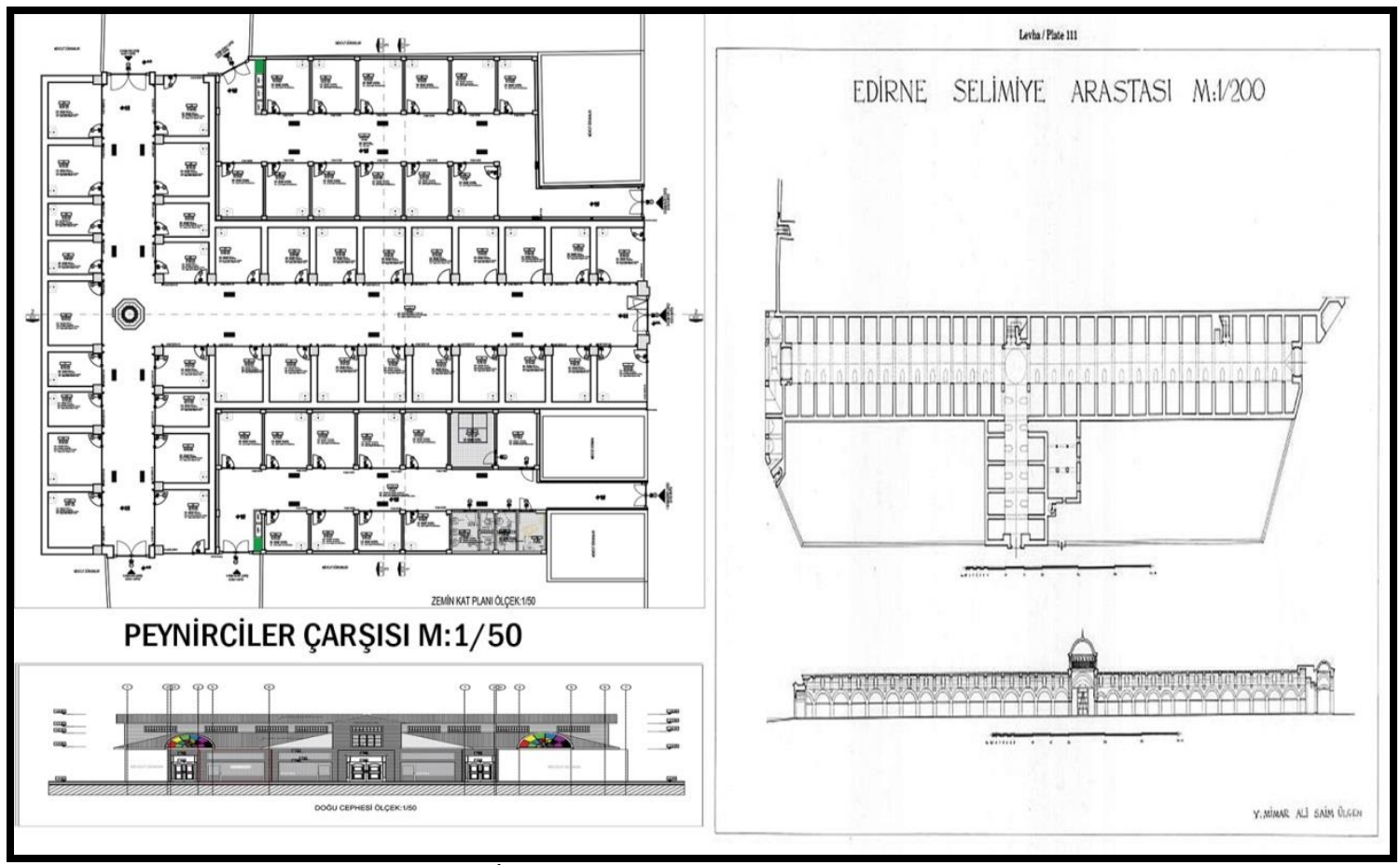

Şekil 4. Tarihi Peynirciler Çarşısı İle Edirne Selimiye Arastası Plan ve Görünüşü( Mimar Murat Karakuş, 2018; Yüksek Mimar Ali Saim Ülgen Arşivi)

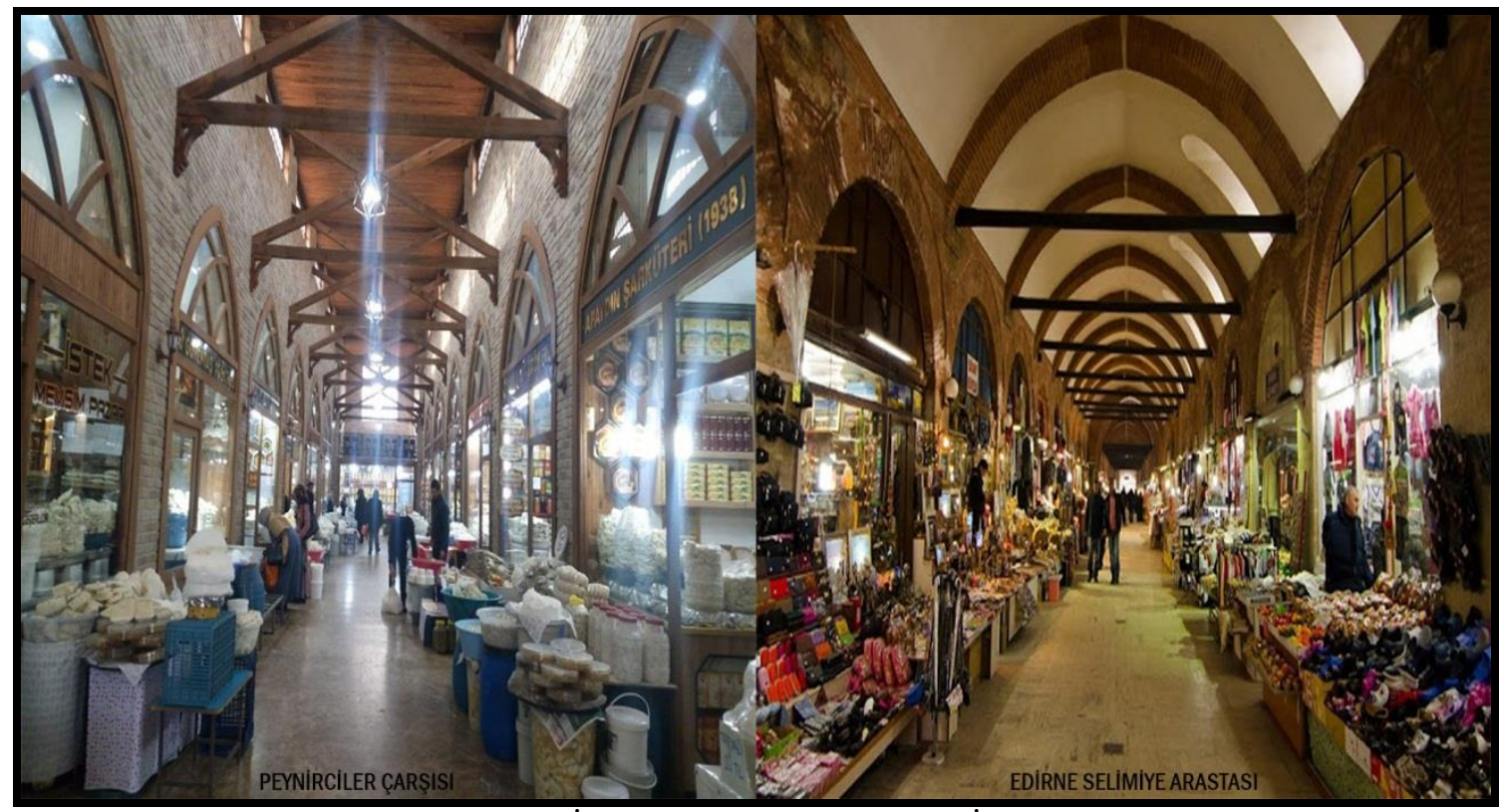

Şekil 5. Tarihi Peynirciler Çarşısı İle Edirne Selimiye Arastası İç Görünüm (Berivan Turan, 2019; URL 5) 


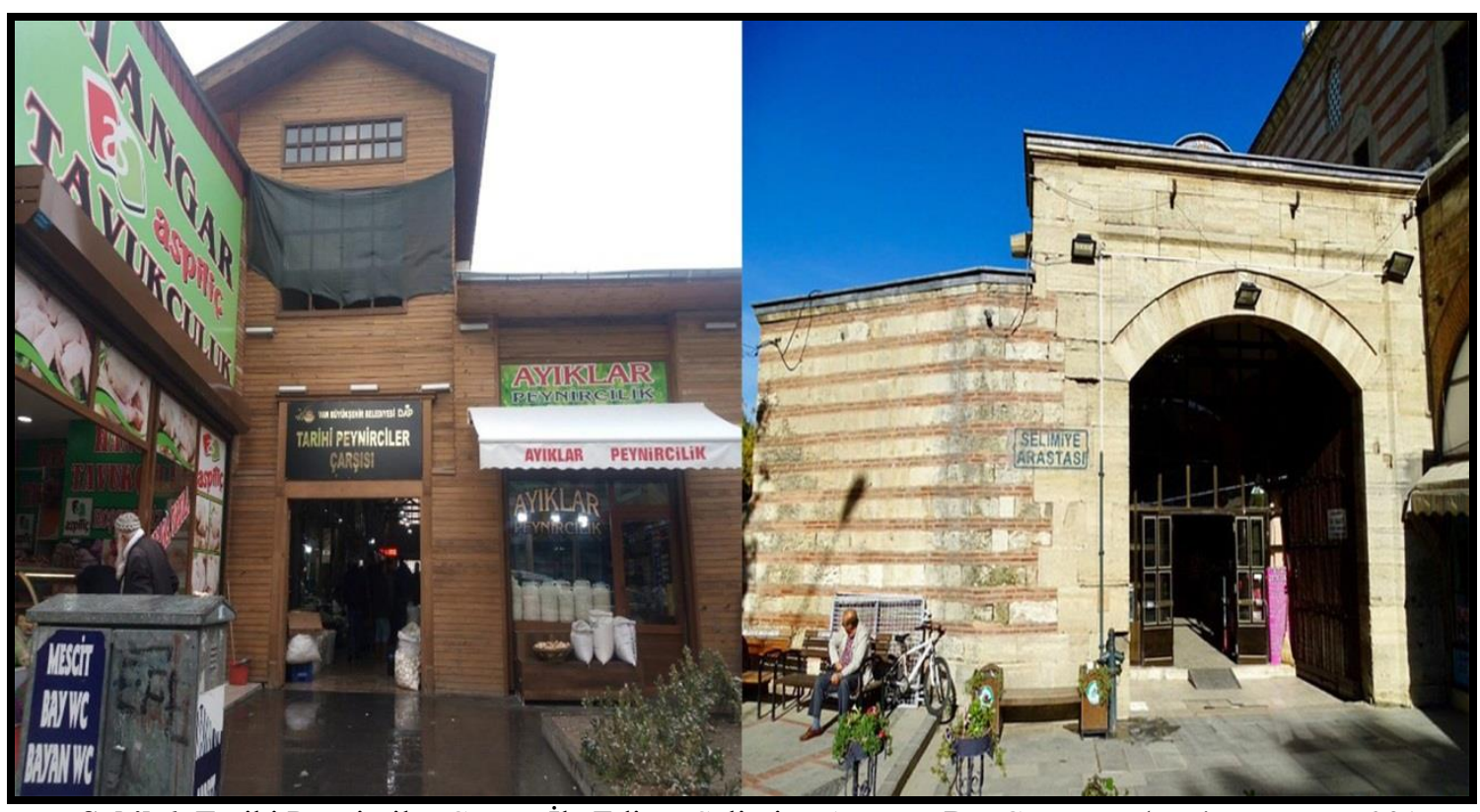

Şekil 6. Tarihi Peynirciler Çarşısı İle Edirne Selimiye Arastası Dış Görünüm (Berivan Turan, 2019; URL 6)

Ana Çarşı dikdörtgen T plan tipinde tek katlı olarak $1550 \mathrm{~m}^{2}$ üzerinde tasarlanmıştır. Malzeme olarak dış ve ara duvarlarda yöresel mimari malzeme olarak kerpiç, taşıyıcı kolonlarda ise tuğla kullanılmıştır. Dükkânlar arasındaki sokak şeklindeki orta koridorun üstü fener çatı tipinde ahşap kâgir ile daha düşük kottaki yan tarafları ise ahşap oturtma çatı ile kaplanmıştır. Çarşının mevcut durumda doğu, güney ve kuzey tarafından üç tane giriş-çıkışı vardır. Batı tarafında bulunan dördüncü giriş ise bitişik nizamdan dolayı kapatılarak, komşu binalar ile çevrelenmiştir. Restorasyon sonra giriş-çıkış sayısı yediye yükselmiştir (Şekil 7). Çarşının özgün dokusunda ilk inşa edildiği günden bu yana önemli değişikler yapılmıştır. Ana Çarşının kuzeyinde ve güneyinde sonradan tek katlı olarak inşa edilen yapıların ikisinde kerpiç duvar ve ahşap döşemeler kullanılmıştır. Dikdörtgen planlı, karşılıklı çift sıralı dükkânların yer aldığı bu iki çarşının ortasında üstü açık avlu bulunmaktadır. Restorasyon sonrası avluların üstü camla kapatılmıştır (Van Büyükşehir Belediyesi, 2017:2). 


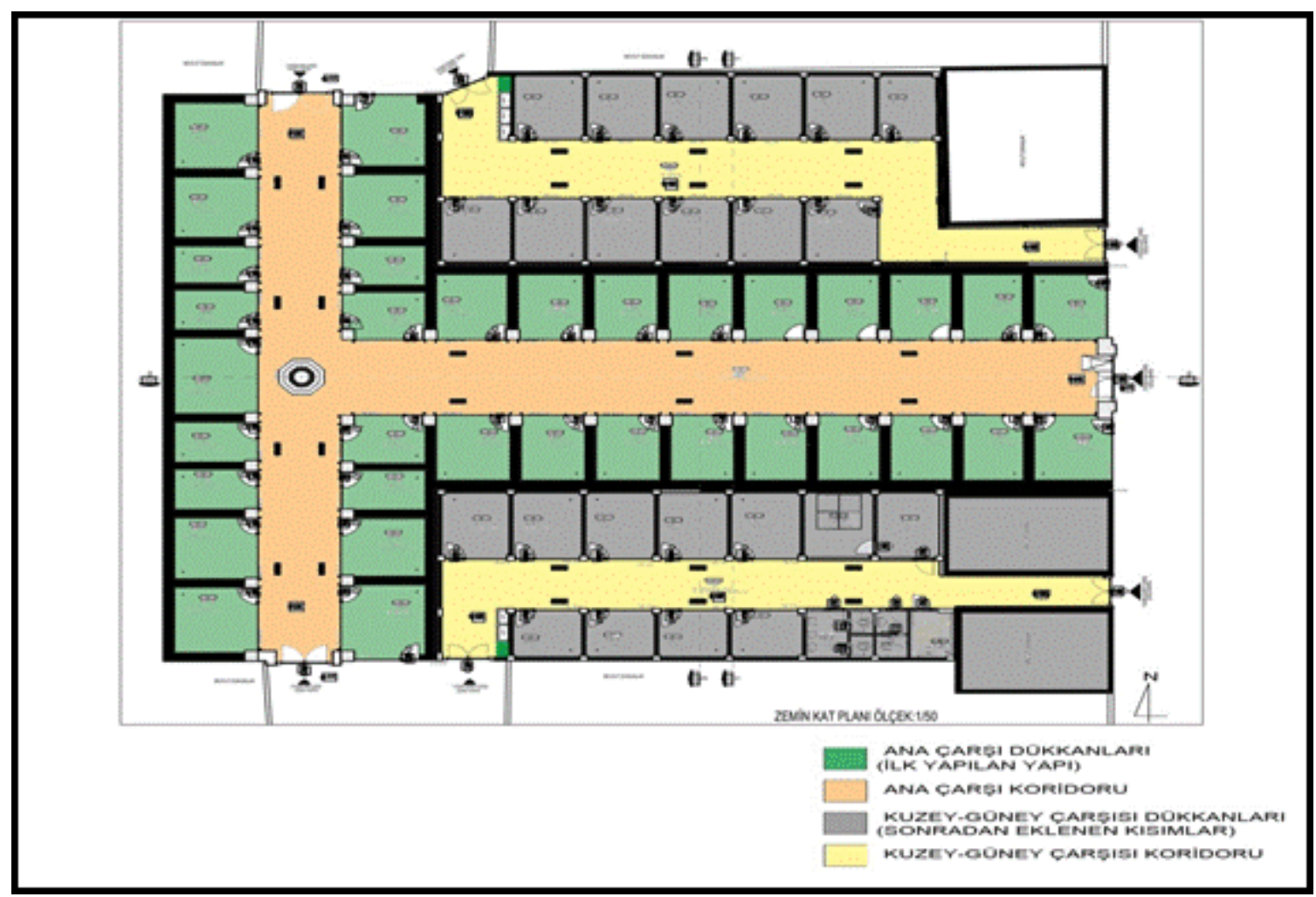

Şekil 7. Tarihi Peynircileri Çarşısı Zemin Kat Planı (Mimar Murat Karakuş, 2018)

\subsection{Koruma Statüsüi}

Tarihi Peynirciler Çarşısının herhangi bir koruma statüsü bulunmamaktadır. Korunması Gerekli Taşınmaz Kültür Varlıklarının ve Sitlerin Tespiti ve Tescilli Hakkındaki Yönetmeliğin 3. Maddesinin m fikrasında taşınmaz kültür varlıkları "tarih öncesi ve tarihi devirlere ait bilim, kültür, din ve güzel sanatlarla ilgili bulunan, o eseri meydana getiren toplumun toplumsal, kültürel, ekonomik, siyasal, bilimsel ya da estetik niteliklerinin belgesi olan yer üstünde, yer altında veya su altındaki korunması gerekli taşınmaz varlıklar" olarak tanımlanmıştır. Madde 4'de ise tespitlerde değerlendirme kıstaslarında arastalar korunması gerekli kültür varlıkları olarak belirlenmiş olup c fikrasında tek yapılar için "taşınmazın sanat, mimari, tarihi, estetik, mahalli, dekoratif, simgesel, belgesel, işlevsel, maddi, hatıra, izlenim, özgünlük, teklik, nadirlik, homojenlik, onarllabilirlik değerlerinin yanı sıra, yapısal durum, malzeme, yapım tekniği, biçim bakımından özellik göstermesi, kent ve çevre kimliğine, dokusuna katkıda bulunmasl, yöresel yaşam biçimini yansıtması" ifadesi kullanılmışır (Korunması Gerekli Taşınmaz Kültür Varlıklarının ve Sitlerin Tespiti ve Tescilli Hakkındaki Yönetmelik, 2012, 12 Mart). Buna göre Tarihi Van Peynirciler Çarşısı tescilli bir yap1 olmamasına rağmen, yapının inşa edildiği döneme ait yapım teknikleri, kullanılan yöresel yapı malzemeleri (kerpiç, ahşap), özgün plan tipi, arasta özelliği taşıması, kent kimliğine etkisi ve yöresel yaşam biçimini yansıtması bakımından taşınmaz kültürel varlığı niteliği taşımaktadır.

\subsection{Yer ve Ürün Markalamada Tarihi Peynirciler Çarşısı Restorasyon Projesi Süreci}

Tarihi Peynirciler Çarşısı Restorasyon Projesi; DAP Bölge Kalkınma İdaresi Başkanlığı ve Van Büyükşehir Belediyesi'nin stratejik planlarında belirtmiş olduğu gibi ürün ve yeri birlikte kullanarak markalaşmayı hedefleyen proje olarak değerlendirilebilir. Proje; ürün olarak coğrafi isimle markalaşan Van Otlu Peynirini yer olarak ise Tarihi Peynirciler Çarşısını kapsamaktadır.

İnşa edildiği yıllarda sebze hali olarak faaliyet gösteren Tarihi Peynirciler Çarşısı ilerleyen yıllarda kasaplarla beraber bir süre kullanılmıştır. 2018 restorasyon projesine kadar Çarşı da sakataţ̧ılar ve peynirciler birlikte yer almıştır (Şekil 
8). 2018 yılında Van Büyükşehir Belediyesi Deprem Risk Yönetimi ve Kentsel İyileştirme Dairesi Başkanlığı Koordinasyonu ve DAP Bölge Kalkınma İdaresi Başkanlığı desteği ile hem Van kentinin tanıtımı hem de kente ait marka değerlerden bir tanesi olan Van Otlu Peynirin yaşatılabilmesi için Tarihi Peynirciler Çarşısı'nın restore edilmesi kararı alınmıştır (Cihangir vd, 2019:748).

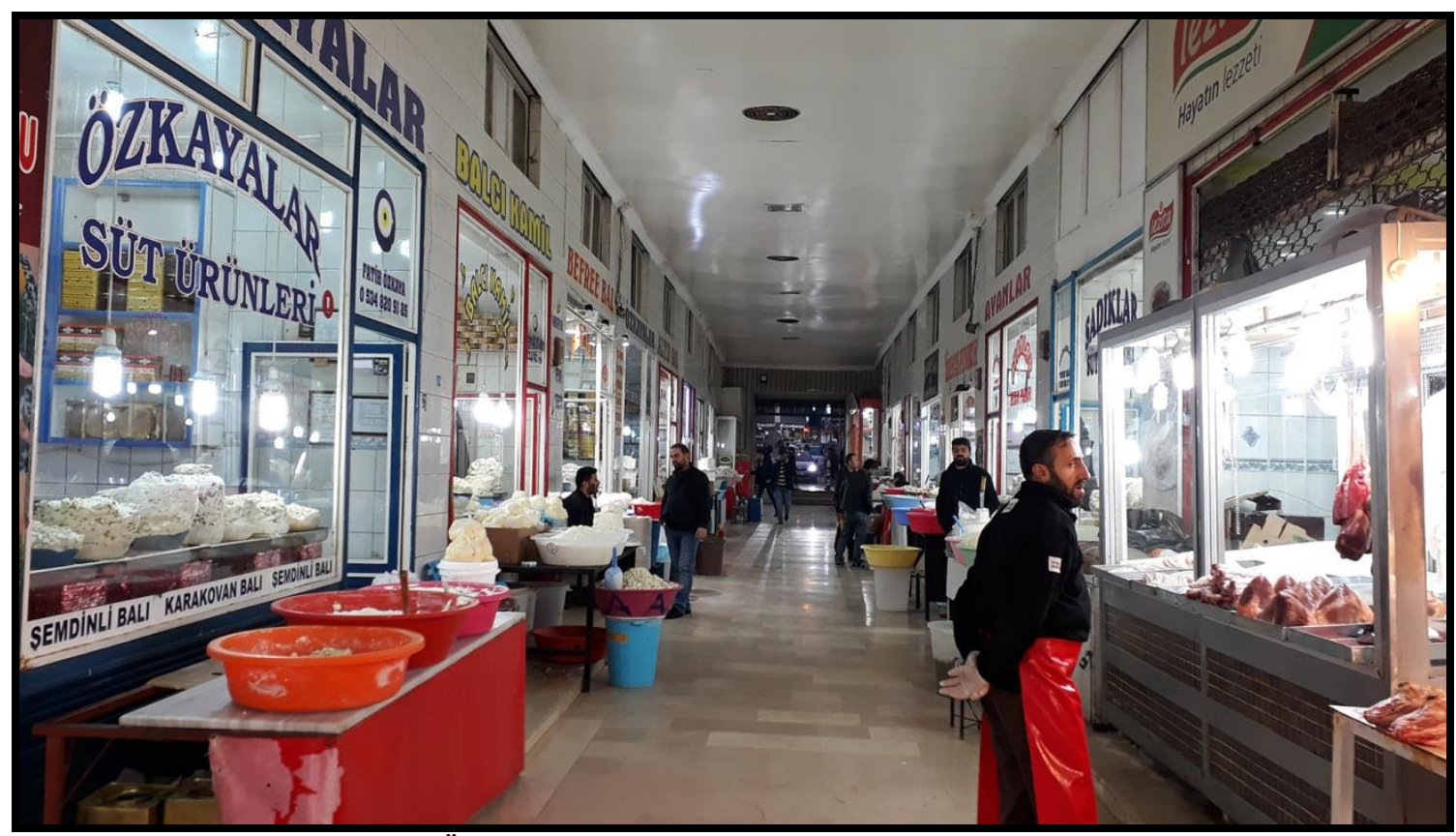

Şekil 8.Restorasyon Öncesi Tarihi Peynirciler Çarşısı (Van Büyükşehir Belediyesi Arşivi, 2019)

2017 yılında Peynirciler Çarşısı Mimari Restorasyon ve Uygulama Projesi, Van Büyükşehir Belediye Başkanlığı Deprem Risk Yönetimi ve Kentsel İyileştirme Daire Başkanlığı tarafından özel bir şirkete verilmiştir. Proje kapsamında restorasyon projesi ve proje raporu hazırlanmıştır. Raporda Tarihi Peynirciler Çarşısı'nın tarihi dokunun korunarak aslına uygun bir şekilde yenilenmesi, bilimsel tekniklere ve mimari restorasyon projesine uygun olarak yapıya müdahale edilmesi ve düzenli bir şekilde kontrol edilmesi, belgelenmesi ve gerektiğinde revize projeler çizilerek proje müellifi tarafından denetlenmesi ilkeleri benimsenmiştir (Van Büyükşehir Belediyesi, 2017:1).

2018 yılının Şubat ayında Van Büyükşehir Belediyesi Genel Sekreteri ve Tarihi Peynirciler Çarşısında yer alan esnaflarla "Peynirciler Çarşıs Mimari Restorasyon ve Uygulama Projesi" hakkında bilgilendirme toplantısı yapılmıştır. Toplantı da Van Büyükşehir Belediyesi, proje ile kentin marka değeri olan Van Otlu Peynir tanıtımının ve esnafın kazancının arttıılmasını hedeflediklerini belirtmiştir (URL 7). 23.03.2018 tarihinde "Tarihi Peynirciler Çarşısı Restorasyon Çalışmaları Yapım işi" Van Büyükşehir Belediyesi tarafından ihale edilmiş ve 20.04.2018 tarihinde ihaleyi özel bir şirket (2.378.232, 47 TL) almıştır. Projenin başlama tarihi 25.06.2018 bitiş tarihi 23.10.2018 olarak belirlenmiş̧ir (EKAP, 2020). Van Büyükşehir Belediyesi Deprem Risk Yönetimi ve Kentsel İyileştirme Dairesi Başkanlı̆̆ koordinatörlüğünde yürütülen restorasyon çalışması dört ay 24 günlük süre sonrasında Kasım 2018 yılında tamamlanmış ve 9 Mart 2019 tarihinde Sanayi ve Teknoloji Bakanı Mustafa Varank tarafından açılışı yapılmıştır (URL 8). Sakatatçıların çarşıdan ayrılması ile birlikte 35 tane olan peynircilere ait dükkan sayısı 55'e yükseltilmiştir. Bu dükkanların 9 tanesi özel mülkiyet 46 tanesi ise Van Büyükşehir Belediyesi'ne aittir. Van Tarihi Peynirciler Çarşısında yer alan toplam 55 adet işletme içinde süt ve süt ürünleri alanında faaliyet gösteren 41 adet girişimci de yer almaktadır (Cihangir vd, 2019:748).

\section{Yöntem ve Bulgular}

Araştırma; markalama kavramını akademik literatürde kent markalama/markalaştırma yaklaşımlarıyla inceleyerek Van kentinin önemli bir marka değeri olan Van Otlu Peynirin satışının yapıldığı Tarihi Peynirciler Çarşısının 
restorasyon projesini yer markalama stratejisi kapsamında değerlendirmeyi hedeflemiştir. Bu hedef doğrultusunda örneklem sayısı nitel verilere göre oluşturulmuştur.

Nitel araştırmalarda güç analizi ve etki büyüklüğü hesaplamaları örneklem sayısını belirlemek için önemli olmasına rağmen odak grup, derinlemesine görüşme gibi nitel araştırmalarda kültürel, sosyal ya da kişisel ifadeleri tanımlayan standart ölçek ya da test henüz oluşturulmamıştır. İstatistiksel güç analizini yapmak için ifadelerin dağılımını belirleyen olasılık modelleri de henüz mevcut değildir (Luborsky ve Rubinstein, 1995: 89-113). Bazı araştırmacılar nitel çalışmalar için bunun hesaplanamayacağını, nitel araştırmaların amacının sonuçlarını tüm evrene genellemek olmadığını, bir ya da iki vakanın (bireyler, gruplar, vb.) yeterli olduğunu belirtmişlerdir (Collins, Onwuegbuzie ve Jiao, 2006; Onwuegbuzie ve Leech, 2007: 105-121). Bununla birlikte Nastasi (2015:1-6), nitel çalışmalarda örneklem büyüklüğünün kullanılan yönteme göre seçilmesi gerektiğini belirterek veri toplama yöntemine göre örneklem büyüklüğü önermiştir (Tablo 2). Buna göre araştırmada ilgili gruplar ile (Van Büyükşehir Belediyesi (3), Proje Müellifi (1), Tarihi Peynirciler Çarşısı esnafı (14), esnaf başkanı (1), arkeolog (1), yerli halk (10) yüz yüze ve telefonla derinlemesine mülakat yöntemi kullanılarak toplamda 30 kişiyle görüşme yapılmıştır.

Tablo 2. Veri Toplama Yöntemine Göre Örneklem Büyüklükleri (Nastasi, 2015:1-6)

\begin{tabular}{|l|l|}
\hline Veri Toplama Yöntemi & Örneklem Büyüklüğ̈̈ \\
\hline Anahtar bilgi görüşmesi & Yaklaşık beş kişiyle görüşme \\
\hline Derinlemesine görüşmeler & Yaklaşık 30 kişiyle görüşme \\
\hline Odak grup görüşmeleri & $\begin{array}{l}\text { Her grupta ortalama 5-10 kişi olacak şekilde gruplar } \\
\text { oluşturulur. Ayrıa odak grupların sayısı araştırma sorusunu } \\
\text { en iyi temsil edecek şekilde belirlenir. }\end{array}$ \\
\hline
\end{tabular}

Araştırmada, çeşitli araştırma yöntemleri kullanılmıştır. Bu araştırma yöntemleri; belgeler (araştırma konusu ile ilişkili kitaplar ve makaleler), Tarihi Peynirciler Çarşısına ait mimari bilgiler, saha araştırması, ilgili gruplarla görüşmeler (yüz yüze derinlemesine mülakat), Van Kültür Varlıklarını Koruma Bölge Kurumu'ndaki kararlar ile ilgili arşiv araştırması, korumaya yönelik kanun ve yönetmelikler gibi yasal belgeler ve son olarak Tarihi Peynirciler Çarşısı Restorasyon Projesidir. Araştırma, amacına uygun olarak yöntemlerine göre üç aşamadan oluşmuştur. Birinci aşama; araştırmanın konusuna ait kavramın arka planını (markalama, pazarlama, yer markalama/ yer pazarlama, kent markalama) içermektedir. İkinci aşama; markalaşmaya yönelik bölgesel ve yerel aktörlerin stratejilerinin belirlenmesini, Van Kahvaltısı ve Van Otlu Peynirinin gastronomi ve marka değer açısından değerlendirilmesini, Tarihi Peynirciler Çarşısının mimari özelliklerini, yapının tarihsel süreçte yapısal ve işlevsel dönüşümünü, Çarşının koruma sorunsalını, Tarihi Peynirciler Çarşısı Restorasyon Projesinin koruma kapsamında analizini ve elde edilen verilerin değerlendirilmesini kapsamaktadır. Son aşama ise; ilgili gruplarla yüz yüze ve telefonla derinlemesine mülakat yapılarak Tarihi Peynirciler Çarşısının restorasyon projesini yer ve ürün markalama stratejisi kapsamında değerlendirmektedir.

\subsection{Tarihi Peynirciler Çarşısı Restorasyon Projesinin Etkileri}

Araştırma kapsamında Tarihi Peynirciler Çarşısı esnafı, çarşı başkanı, proje müellifi, Van Büyükşehir Belediyesi teknik personeli ve yerli halk ile toplamda otuz kişi ile yüz yüze ve telefonla derinlemesine mülakat yapılarak restorasyon hakkındaki görüşleri ve otlu peynir satışlarındaki değişime yönelik memnuniyetleri tespit edilmeye çalışılmıştır. Peynirciler Çarsındaki on dört esnaf ile yapılan yüz yüze mülakatta; restorasyon projesinin mekan kalitesine etkisi, yöresel ürünlere yönelik marka bilinci, ürün satışlarındaki değişim, müşteri çeşitliliği, esnaflık mesleğine ve yere bağlılığın belirlenmesi amaçlanmıştır. Buna göre mekan kalitesi açısından restorasyon projesi kapsamında sakatatçıların çarşıdan ayrılması ile daha sağlıklı mekanların oluştuğu belirtilmiştir. Fakat Restorasyon sonrasında projede kullanılan ahşap malzemelerin suya dayanıksız olması, işçiliğin kalitesiz olması ve kış aylarında ısınma sorunu yaşamalarından dolayı projeye yönelik memnuniyetlerinin az olduğu ifade edilmiştir.

Esnaflık mesleğine ve yere bağl1lık ile yöresel ürünlere yönelik marka bilinci kapsamında; Tarihi Peynirciler Çarsısında bulunan çoğu esnafın bu mesleği babadan oğula devraldığını ve en az sekiz yıl en fazla ise otuz beş yıldır bu mesleği Tarihi Peynirciler Çarsısında icra ettiklerini, bu nedenle Çarşıya yönelik aitlik hissinin oluştuğunu, sosyal anlamda esnafin birbirleriyle ve müşterilerle olan bağlarının güçlü olduğunu, bazı müşterileri uzun süredir çarsıda 
alışveriş yaptıkları için tanıdıklarını ve bu müşteriler ile ilişkilerinin geliştiğini, yöresel ürünler satmanın onlara bu işi daha da sevdirdiğini ve Van Otlu Peynirin tescillenmesinin peynirciler esnafina olumlu katkı sağladığını belirtmişlerdir.

Esnafin en çok şikayetçi olduğu konu ise ekonomik olarak projenin ürün satışlarına etkisidir. Ürün maliyetlerinin artmasından dolayı otlu peynir satışlarının eskiye oranla ciddi derecede azaldığını, kira ücretlerinin çok fazla arttı̆̆ını ve Peynirciler Çarşısı dışındaki mekanlarda da (firınlarda, bakkallarda, marketlerde) peynir satılmasından rahatsız oldukları ifade etmişlerdir. Özellikle bir esnafın "eğer Van'ın her yerinde peynir satılıyorsa Peynirciler Çarşısı diye bir kavram yoktur demek ki" ifadesi ürün ve yer arasındaki bağın kopukluğuna vurgu yapmaktadır. Son olarak müşteri çeşitliği açısından yerli (İstanbul, Ankara, Bursa, İzmir, Diyarbakır, Batman, Mersin, Mardin) ve yabancı turistlerin (Danimarka, Kanada, Fransa, Almanya, İzlanda, Norveç, Amerika) yerli halka oranla daha fazla peynir satın aldıklarını belirtmişlerdir.

Proje öncesi, restorasyon sürecini anlamak adına Çarşı Başkanı Hasan Kayhan ile derinlemesine mülakat yapılmıştır. Mülakat sonucunda restorasyon kararından sonra uygulama aşamasında esnafın görüşünün tam olarak alınmadı̆̆ projenin daha sağlıklı mekanlar yarattığı ancak kullanılan malzemenin kalitesinin düşük ve işçiliğin ise iyi olmadığını belirtmiştir. Projeye yönelik büyük beklentilerinin olduğunu ancak bu beklentilerin proje sonucu karşılanamadığı, kira fiyatlarının \%120 artığını ve dükkanların konumuna göre kira artış miktarının değiştiğini ifade etmiştir (Kayhan, 2020).

Peynirciler Çarşısı Mimari Restorasyon ve Uygulama Projesi proje müellifi Mimar Murat Karakuş ile mimari proje ve uygulamaya yönelik düşünceleri hakkında telefon ile görüş̧e yapılmıştır. Karakuş; yapının tarihi özellik gösterdiğini ve kentin imajı için önemli olduğunu, restorasyon projesinde tarihi dokunun korunması ve aslına uygun bir şekilde yenilenmesinin amaçlandığını, bu amaç doğrultusunda özel imalat gerektiren yapım işlerinin olduğunu (kerpiç, çatı malzemesi), yapıya yönelik müdahale biçimlerinin çoğunun uygulandığını ancak uygulamanın yüklenici firma ve Belediye tarafından yürütüldüğünü, proje müellifinin denetimde bulunmadığını ve danışmanlık hizmeti yapmadığını, bu nedenle özel imalat gerektiren malzemelerin yapımında ve uygulanmasında teknik sorunlar yaşandığını, malzeme kalitesi ve iş̧̧iliğin düşük olduğunu ifade etmiştir. Ayrıca rölöve esnasında çarşıdaki esnafla bilgilendirme amaçlı görüşmelerin yapıldığını belirtmiştir (Mimar Murat Karakuş ile Mülakat, Şubat-18-2020) .

Van Büyükşehir Belediyesi Deprem Risk Yönetimi ve Kentsel İyileştirme Dairesi Başkanlığındaki teknik personellerle yapılan yüz yüze görüsşmeler sonucunda ise, restorasyonun projeye uygun yapıldığı, maliyetin \%10 iş artış ve KDV ile 3.000.021 TL'ye yükseldiği, esnaf ile proje hakkında bilgilendirme görüşmeleri yapıldığı ve proje sonrasında kullanıcılardan kaynaklı sorunların yaşandığı ifade edilmiştir. Yerli halk ise Tarihi Peynirciler Çarşının restorasyon sonrası görünümünden memnun olduklarını fakat alım gücünün düşmesinden ve peynir fiyatlarının artmasından dolayı çok fazla alışveriş yapamadıklarını belirtmişlerdir.

\section{SONUÇ ve ÖNERILER:}

2017-2019 yılları arasında yaklaşık olarak iki yıllık süreç içerisinde şekillenen ve uygulanan Tarihi Peynirciler Çarşısı Restorasyon Projesi; yer ve ürün markalama stratejisi kapsamında yerel ve bölgesel aktörlerin öncülük ederek başlatmış olduğu, Van Otlu Peyniri marka değerinin korunmasına yönelik satışının yapıldığı taşınmaz kültürel varlık niteliğindeki tarihi yapının restorasyonunun gerçekleştirildiği, ilgili paydaşların ve üreticilerin sürece dahil edilerek işbirliği-iletişimin sağlandığı, ulusal ve yerel basında Van Otlu Peyniri ve Tarihi Peynirciler Çarşısının tanıtımının yapıldı̆̆

Yapılan mülakatlar ve gözlemler sonucunda Tarihi Peynirciler Çarşısı Restorasyon Projesi mekan kalitesi açısından, malzemenin kalitesinin düşük ve işçiliğin ise iyi olmamasına rağmen, kullanıcılar tarafindan memnuniyet oluşturmuştur. Ancak, ürün maliyetlerinin artmasından dolayı peynir satışının az olması, kira fiyatlarının artması ve dükkan sayılarının fazla olması ekonomik anlamda esnafı olumsuz etkilemiştir. Ürün maliyeti Türkiye genelinde özellikle hayvancılık sektöründe arttı̆̆ için proje, ürün maliyetinin artışına doğrudan etki etmemektedir, ancak kira fiyatlarının artmasında doğrudan etkilidir.

Tarihi Peynirciler Çarşısı'ndaki müşteri çeşitliği, Van Otlu Peynirinin ulusal ve uluslararası kamuoyunda tanınırlığını ve gastronomik bir değer olarak marka oluşturduğunu göstermektedir. 
Yer markalama, bir yerle belirli duygusal ve psikolojik ilişkiler kurarak insanların fikirlerini etkileyebilmektedir. Buna göre Tarihi Peynirciler Çarşısı'ndaki esnafların mesleğine ve yere bağlılıkları sosyal, duygusal ve psikolojik ilişkilerle yeri markalamaktadır.

Kentlerdeki markalaşma ağırlıklı olarak geleneksel ürün/üretim ve mimari yapılarda görülmektedir. Bu bağlamda Tarihi Peynirciler Çarşısı Restorasyon Projesi; kültür, tarih, gastronomi, yere bağlılık ve mekan kalitesi kapsamında yer ve ürün markalama stratejisi olarak kent markalaşmasına yönelik bir adım olarak değerlendirilebilir.

Van kentine ait öne çıkan marka ürün ve değerler; Van Otlu Peyniri, Van Kahvaltısı, yöresel yemekler (ayran aşı, çılbır, çiriş pilavı, kurut aşı, tandırda inci kefali, vb.), Ermeni mimarisini yansıtan kiliseler, Urartu dönemine ait kaleler, Eski Van Şehri, Muradiye Şelalesi, Çarpanak, Adır ve Akdamar Adası ile Van Gölüdür. Van kentine yönelik bu ürünleri ve değerleri bütüncül bir yaklaşımla dikkate alabilen markalaşma stratejileri; kente sosyal, kültürel ve ekolojik çerçevede ekonomik girdi de oluşturabilir.

Sonuç olarak; tarihi yapılar ve yöresel lezzetler bir kentin kültürel mirasını öne çıkaran değerlerdir. Kentler bu değerler doğrultusunda kentsel markalaşma stratejisi belirleyerek politik ya da organik müdahaleler ile küresel rekabette yer almaya çalışmaktadır. Markalaşma stratejileri ilgili paydaşların katılımıyla gerçekleştirildiğinde sürdürülebilir başarılar elde edebilir. Van kentine yönelik markalama stratejisi, Van Kahvaltısı ve Van Otlu Peyniri kapsamında ürün ve yer birlikte kullanılarak yapılmaktadır. Tarihi Peynirciler Çarşısı örneğinde de görüldüğü gibi yerel ve bölgesel aktörlerin politik müdahalesi sonucu esnafın da görüşü alınarak uygulanan restorasyon projesi; tarihi yapının korunması, kültürel miras bilincinin artırılması, yöresel ürün olan Van Otlu Peynirinin marka değerinin ürün ve kent bazında gastronomik imaj yaratması ve yapının ekonomik ve kültürel fonksiyonlarla kente kazandırılması açısından önemlidir. Ancak kent markalaşması bir dizi faaliyetleri kapsayan markalaşma stratejilerinden oluştuğu için Van ölçeğinde birkaç projenin yapılması kentin markalaşması olarak değerlendirilmemelidir. Kentsel markalaşma stratejileri süreç olarak; katılımcı yaklaşım anlayışıyla ilgili aktörlerin sürece katılması, markalama tanımı ve ölçütlerin belirlenmesi, markalama stratejilerinin oluşturulması, oluşturulan stratejilerin kent kimliği, kent imajı ve turizm ile ilişkilendirilerek tanıtımının yapılmasını kapsamaktadır. Bu süreç çerçevesinde oluşturulan stratejiler sosyal, ekonomik ve kültürel boyutta katkı sağladığında ancak bir kentin markalaşmasından söz edilebilir.

\section{Etik Standart ile Uyumluluk}

Çıkar Çatışması: Çıkar çatışması bulunmamaktadır.

Etik Kurul İzni: Bu çalışma için etik kurul iznine gerek yoktur.

\section{Teşekkür:}




\section{KAYNAKÇA:}

\section{Kitaplar:}

CERRETA, M. , ve DALDANISE, G., (2017). Community Branding (Co-Bra): A Collaborative Decision Making Process for Urban Regeneration, ICCSA 2017, Part III, LNCS 10406, 730-746.doi: 10.1007/978-3-319-62398-6_52.

\section{Bildiriler:}

CIHANGÍR, E. , CIHANGIR, K.Ç., DEMIRHAN, Ö. ve ŞEREMET, M. (2019). "Van Tarihi Peynirciler Çarşısının Turizm Sektörü ve Turizm Girişimciliği Açısından Değerlendirilmesi', IWACT'19 Internetional West Asia Congress of Tourism Research, 26-29 September 2019 Van, TURKEY, The Congress Book of Proceedings,ISBN: 978-605-7691-34-7. 743-755.

DEMIRHAN, Ö., CIHHANGİR, E. ve ŞEREMET, M. (2019). “Turistik Ürün Olma Yolunda Geleneksel Van Otlu Peyniri ve Kırsal Kadının Rolü', IWACT'19 Internetional West Asia Congress of Tourism Research, 26-29 September 2019 Van TURKEY, The Congress Book of Proceedings,ISBN: 978-605-7691-34-7. 660-675.

SEISDEDOS, G. ve VAGGINE, P. (2005). The City Branding Processes: the case of Madrid,41st ISoCaRP Congress 2005, 1-10. Erişim Tarihi:10.03.2020. http://www.isocarp.net/Data/case_studies/658.pdf

\section{Makaleler:}

AKAR, T. (2009). Osmanlı Kentinde Ticari Mekânlar: Bedesten-Han-Arasta-Çarşı Mekânları Literatür Değerlendirmesi, Türkiye Araştırmalar Literatür Dergisi, Cilt 7, Sayı 13. 267-292. Erişim Tarihi: 12.01.2020. https://www.academia.edu/38528407/Osmanl\%C4\%B1_Kentinde_Ticari_Mek.

AKTURAN, U. ve OĞUZTiMUR, S. (2016). Kent Markalaşması Kavramının İçeriği ve Gelişimi: Farklı Disiplinler Farklı Yaklaşımlar, Planlama2016 26(2): 117-129.doi: 10.14744/planlama.2016.76376.

COLliNS, K. M. T., ONWUEGBUZIE, A. J., ve JIAO, Q. G. (2006). Prevalence of mixed-methods sampling designs in social science research. Evaluation \& Research in Education, 19 (2), 83-101.

ESHUIS, J., KLIJN, E.H., ve ERIK, B. (2014). Place marketing and citizen participation: branding as strategy to address the emotional dimension of policy making? International Review of Administrative Sciences, 80(1), 151-171. Doi:10.1177/0020852313513872

KAVARATZIS, M. (2004). From city marketing to city branding: Towards a theoretical framework for developing city brands. Place Brand Public Dipl 1, 58-73. https://doi.org/10.1057/palgrave.pb.5990005

KAVARATZIS, M. ve ASHWORTH, G. (2006). City branding: An effective assertion of identity or a transitory marketing trick?. Place Brand Public Dipl 2, 183-194. https://doi.org/10.1057/palgrave.pb.5990056

PARKER, C., STUART, R., ve DOMINIC, M. (2015). Back to basics in the marketing of place: the impact of litter upon place attitudes, Journal of Marketing Management31(9-10),1-23.doi:10.1080/0267257X.2015.1035307 


\section{Web Sitesi:}

DAKA, (2013). Doğu Anadolu Kalkınma Ajans1 (DAKA) 2014-2023 Dönemi TRB2 Bölgesi Bölge Plan1, 18.12.2019 tarihinde, https://www.daka.org.tr/panel/files/files/yayinlar/trb2_2014_2023_bp.pdf adresinden erişildi.

DAP, (2014). DAP Bölge Kalkınma İdaresi Başkanlığı, Doğu Anadolu Projesi Eylem Planı (2014-2018), 16.12.2019 tarihinde, http://www.sp.gov.tr/upload/xSPTemelBelge/files/mnlom+DAP_Eylem_Plani_2014-2018.pdf. adresinden erişildi.

EKAP, (2020). Elektronik Kamu Alımları Platformu (EKAP), Tarihi Peynirciler Çarşısı Restorasyon Çalışmaları Yapım işi İhale Arama Sonucu. 05.01.2020 tarihinde, https://ekap.kik.gov.tr/EKAP/Ortak/IhaleArama/index.html adresinden erişildi.

GOOGLE EARTH, (2019). Tarihi Peynirciler Çarşıs1 Uydu Görüntüsü. Erişim Tarihi: 05.02.2020. https://earth.google.com/web/

\section{KORUNMASI GEREKLİ TASINMAZ KÜLTÜR VARLIKLARININ VE SITLERİN TESPITTI VE TESCILLİ HAKKINDAKİ YÖNETMELIK, (2012, 12 MART). Resmi Gazete (Say1:28232). \\ https://www.resmigazete.gov.tr/eskiler/2012/03/20120313-6.htm}

NASTASI, B. (2015). Study notes: qualitative research: sampling ve sample size considerations. 1-6. Erişim Tarihi: 10.07.2020. https://www.studypool.com/documents/90822/sampling-sample-size-considerations-adapted.

Onwuegbuzie, A. J. ve Leech, N.L. (2007). A Call for qualitative power analyses. Quality \& Quantity, 41, 105-121.

URL 1: http://www.milliyet.com.tr/gundem/van-kahvaltisiyla-guinness-rekorlar-kitabina-girdi-1890913, (2014). Erişim Tarihi: 10.10. 2019.

URL 2: https://online.turkpatent.gov.tr/trademarksearch/pub/\#trademark_result_detail, (2014). Erişim Tarihi: 10.10.2019.

URL 3: https://www.ntv.com.tr/seyahat/van-kahvaltisi-unescoyla-dunyaya tanitilacak,9feLCtSIQkmMq73iVEKmiQ, (2019). Erişim Tarihi: 9.02.2020.

URL 4: http://www.vansesigazetesi.com/yazar-van-kent-kimliligine-kavusuyor-4700.html, (2018). Erişim Tarihi: 06.12.2019.

URL 5: https://www.oteledirne.com/arasta-carsisi.html, (2016). Erişim Tarihi: 06.12.2019.

URL 6: https://www.azbibak.com/selimiye-arastasi-hakkinda-bilgi/, (2018). Erişim Tarihi: 06.12.2019.

URL 7: https://www.milliyet.com.tr/yerel-haberler/van/yalcin-peynirciler-carsisi-esnafiyla-bir-araya-geldi-12582860, (2018). Erişim Tarihi:06.12.2019.

URL 8: https://www.gundemvan.com/van-in-tarihi-peynirciler-carsisi acildi/21790/, (2019) Erişim Tarihi: 15.01.2020.

VAN İL TARIM VE ORMAN MÜDÜRLÜĞÜ, ( 2020). Tarım ve Orman Bakanlığı Van İl Tarım Ve Orman Müdürlüğü “Otlu Peynir”. Erişim Tarihi: 10.01.2020. https://van.tarimorman.gov.tr/Sayfalar/Detay.aspx?SayfaId=20.

VUIGNIER, R. (2016). Place marketing and place branding: A systematic (and tentatively exhaustive) literature review, HAL archives-ouvertes, 1-93. Erişim Tarihi: 01.04.2020. https://hal.archives-ouvertes.fr/hal-01340352 


\section{Raporlar:}

VAN BÜYÜKŞEHİR BELEDIYESI, (2014). 2015-2019 Van Büyükşehir Belediyesi Stratejik Planı, Van.

VAN BÜYÜKŞEHIR BELEDIYYESI, (2017). Van Büyükşehir Belediyesi Deprem Risk Yönetimi ve Kentsel İyileştirme Daire Başkanlığı, "Peynirciler Çarşısı Proje Raporu”, ETÜT MIMM. MÜH. İNŞ. İTH. İHR. SAN. LTD. şíT.

\section{Tezler:}

ZENGIN, E. (2017). Küreselleşme Sürecinde Kent Markalama: Model Önerisi Bartın Örneği. Yüksek Lisans Tezi. Marmara Üniversitesi, Sosyal Bilimler Enstitüsü, Halkla İlişkiler Anabilim Dalı, İstanbul.

\section{Fotoğraflar:}

TURAN, B. 2019. Berivan Turan Orijinal Fotoğraf.

VAN BÜYÜKŞEHİR BELEDIYESİ ARŞIVI, 2019. Van Büyükşehir Belediyesi Deprem Risk Yönetimi ve Kentsel İyileştirme Dairesi Başkanlığı Koordinasyonu Fotoğraf Arşivi.

MIMAR MURAT KARAKUŞ, 2018; YÜKSEK MIMMAR ALİ SAİM ÜLGEN ARŞİí. Mimar Murat Karakuş Tarihi Peynirciler Çarşısı Restorasyon Projesi. 